\title{
Physical Properties of Juvenile and Mature Sycamore Maple (Acer pseudoplatanus L.) Wood from Medvednica Region
}

\section{Fizička svojstva juvenilnoga i zrelog drva gorskog javora (Acer pseudoplatanus L.) s područja Medvednice}

Original scientific paper $\bullet$ Izvorni znanstveni rad

Received-prispjelo: 8. 11. 2017.

Accepted-prihvaćeno: 10. 12. 2018.

UDK: $630 * 811.4 ; 630 * 812.23 ; 630 * 812.31 ; 630 * 815.321$

doi: $10.5552 /$ drvind.2019.1762

\begin{abstract}
Physical properties play an important role in predicting wood quality. The aim of this study was to investigate radial variations in physical properties of sycamore maple (Acer pseudoplatanus L.) wood, to determine the border between juvenile and mature wood and to compare them with analogous variations in beech wood. Radial variation of density in absolutely dry condition, maximum density, nominal density, longitudinal, radial, tangential and volumetric shrinkage, maximum moisture content and annual ring width on five sycamore maple trees from Medvednica region in Croatia were determined. Observing the trend curves and comparing average values of physical properties, different zones in the cross section of the trunk were determined. In the first zone, from the pith to about 30th annual ring, more rapid changes in physical properties occurred. It is followed by transitional zone, which ranges roughly from 30th to 40th annual ring. After 40th annual ring, less pronounced changes in measured physical properties occurred. Sharp boundary between juvenile and mature wood zones could not be determined. According to the results, the first zone is considered to be juvenile wood, while mature wood starts after the 30th annual ring.
\end{abstract}

Key words: sycamore maple (Acer pseudoplatanus L.), physical properties, radial variations, juvenile wood, mature wood

SAŽETAK • Fizička svojstva drva imaju važnu ulogu u predviđanju njegove kvalitete. Cilj ovog rada bio je istražiti radijalne varijacije fizičkih svojstava drva gorskog javora (Acer pseudoplatanus L.), utvrditi granicu između juvenilnoga i zrelog drva te ih usporediti sodgovarajućim varijacijama u drvu bukve. Utvrđene su radijalne varijacije gustoće u apsolutno suhom stanju, gustoća pri maksimalnom sadržaju vode, nominalna gustoća, longitudinalno, radijalno, tangentno $i$ volumno utezanje, maksimalni sadržaj vode $i$ širina godova u drvu pet stabala gorskog javora s Medvednice u Hrvatskoj. Iz dobivenih krivulja i usporedbe prosječnih vrijednosti fizičkih svojstava drva utvrđene su različite zone na poprečnom presjeku debla. U prvoj zoni, od srčike do približno 30.

\footnotetext{
${ }^{1}$ Authors are senior assistant, professor, professor, associate professor, senior assistant and associate professor at Department for Wood Science, Faculty of Forestry, University of Zagreb, Zagreb, Croatia.

${ }^{1}$ Autori su poslijedoktorand, redoviti profesor, redovita profesorica, izvanredni profesor, poslijedoktorandica i izvanredni profesor u Zavodu za znanost o drvu, Šumarski fakultet Sveučilišta u Zagrebu, Zagreb, Hrvatska.
} 
goda, vidljive su znatnije promjene fizičkih svojstava drva. Slijedi prijelazna zona, koja se otprilike proteže od 30. do 40. goda. Nakon 40. goda promjene fizičkih svojstava drva manje su vidljive. Oštru granicu između zona juvenilnoga i zrelog drva nije moguće odrediti. Na temelju dobivenih rezultata pretpostavljeno je da je prva zona juvenilno drvo, a nakon 30. goda počinje zrelo drvo.

Ključne riječi: gorski javor (Acer pseudoplatanus L.), fizička svojstva, radijalne varijacije, juvenilno drvo, zrelo drvo

\section{INTRODUCTION}

1. UVOD

Sycamore maple (Acer pseudoplatanus L.) is native mainly to the mountainous regions of Southern, South-Western, Western, Central and Eastern Europe with the extreme easterly limit at the Caspian Sea (Krabel and Wolf, 2013). It grows at 300 to 2000 meters above sea level (Spethmann and Namvar, 1985) and it grows almost always together with beech. In many parts of Europe, sycamore maple is considered invasive and exotic species, therefore causing some debate among forest breeders and conservators. Some of them believe that sycamore maple should be eradicated in areas where it threatens the ancient indigenous forests (Rusanen and Myking, 2003). Others speak of great economic value and potential of reforestation with sycamore maple as it is considered as hardwood species whose value grows in Central Europe (Kleinschmit et al., 2009).

In Europe, $1.7 \%$ of the total annual cuttings consist of sycamore maple. Approximately $0.8 \%$ of forests in Croatia are covered with sycamore maple (Hrvatske šume, 2014). Researchers claim that the future share of ash, sycamore maple and wild cherry in Europe will double; therefore, the future share of sycamore maple harvest could increase remarkably (Thies et al., 2009). These three species currently cover $4.1 \%$ of the European forests, and in future they are expected to reach up to $8.9 \%$ and for German speaking countries $12.1 \%$ (Thies et al., 2009). According to Kölling and Zimmermann (2007) and Kölling (2007), sycamore maple is considered a well adapted species to current and also to predicted future climate conditions in Central Europe. Due to its highly valuable timber, short generation turnover and fairly regular seed set, sycamore maple may increase in importance economically, which may encourage breeders to embark on more breeding programs (Rusanen and Myking, 2003).

Available information on physical properties of sycamore maple wood and on their radial variations is modest, and there is no science based information on many important technical properties of sycamore maple wood. Growing quantities of sycamore maple expected in the near future, along with the lack of scientifically based, confirmed and tested information on the properties of sycamore maple wood and on their radial variation, have all led to the present research. This paper describes research on physical properties and variation in their distribution from pith to bark in sycamore maple wood from Medvednica region. Mountain Medvednica represents natural habitat with mild continental climate, where sycamore maple grows together with beech, regionally characteristic community AceriFraxinetum croaticum Horvat (Vukelić, 1998).
The aim of the study was to investigate variations in properties of sycamore maple wood in radial direction, to determine the border between juvenile and mature wood and to compare them with analogous variations in beech wood. This is partly necessary due to insufficient data on maple wood properties, partly due to habitat shared with beech and partly due to their similar diffuse porous wood structure.

\section{MATERIALS AND METHODS 2. MATERIJALI I METODE}

For the purpose of this research, the location of Mount Medvednica, specifically its northern slope was selected. This area is part of the "Training and Forest Research Centre Zagreb", managed by the Faculty of Forestry in Zagreb. Mountain Medvednica represents a natural habitat with mild continental climate, where sycamore maple grows together with beech.

Five representative sycamore maple trees from different diameter classes were selected using the method of random sampling. The test trees were chosen as representative of the stand according to ISO 3129:1999. After cutting down the tree, a test log of 1 $\mathrm{m}$ in length was sawn from each test tree. The measurement of the test log length started at breast height (1.3 $\mathrm{m})$, upwards to the crown. Afterwards, these $1 \mathrm{~m}$ long trunks were sawn into 'bark to bark' cores, approximately $6 \mathrm{~cm}$ thick. One core was oriented north-tosouth, and the other east-to-west (Figure 1). Cores were then submitted to natural drying. After the cores had dried to a water content of about $12 \%$, parts of the cores, which were in the area of the breast height (1.3 $\mathrm{m})$, were sawn out into rectangular samples of $20 \mathrm{~mm}$ $\times 20 \mathrm{~mm} \times 25 \mathrm{~mm}$. The samples were sawn in radial direction from pith to bark and labelled with markers

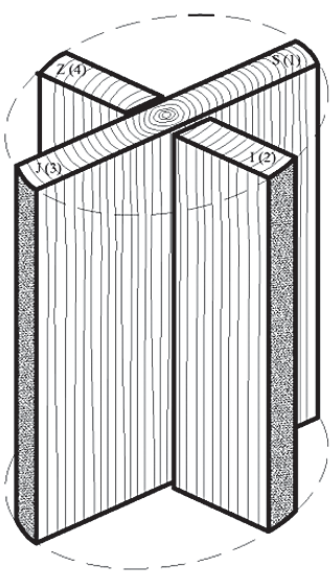

Figure 1 Bark to bark cores (north - south, east and west) Slika 1. Srednjača (sjever - jug, istok i zapad) 
indicating from which tree they were sawn, their orientation and the ordinal number from pith to bark.

Physical properties of juvenile and mature wood researched in this study were density in absolutely dry condition, maximum density and nominal density according to HRN ISO 3131:1999, longitudinal, radial and tangential shrinkage according to HRN ISO 4469:1999, volumetric shrinkage according to HRN ISO 4858:1999, maximum water content according to HRN ISO 3130:1999 and annual ring width according to HRN D.A1.042-1957.

Statistical analysis of the data and their comparison were carried out in Statistica 8. Statistical analysis has shown the number of measured samples, average value of certain measured properties, as well as their standard deviation. Comparison between properties of juvenile and mature wood was carried out by MannWhitney test.

\section{RESULTS AND DISCUSSION}

3. REZULTATI I RASPRAVA

Analysing data of investigated physical properties of sycamore maple wood and their distribution in radial direction, it could be assumed that there is a transitional area of juvenile wood to mature wood (Govorčin, 1996; Zobel and van Buijtenen, 1989), from around 30th to 40th annual ring. For the purpose of statistical analysis, the 30th annual ring is taken as a boundary between the zones of juvenile and mature wood.

Annual ring width has a higher average value in the zone from the 1 st to the 30 th annual ring (Table 1). The difference in average values of annual ring width in two investigated zones is statistically significant (Table 2). Such arrangement of annual ring width agrees with the conclusions of Petrić and Bađun (1985) and Senft (1986), who state that annual rings are usually much wider in juvenile wood than in mature wood. They also concluded that annual ring width, under normal growth conditions, decreases from pith to bark. Figure 2 shows that the annual ring width in tested sycamore trees had a growing trend in the area of 30th40th annual ring, and then decreased towards the bark. On the contrary, Govorčin (1996) recorded that the average annual ring width in juvenile beech wood is narrower than the one in mature wood.

The average values of density in absolutely dry condition, maximum density and nominal density of

Table 1 Statistical values of researched macroscopic and physical properties of Zone $1-30$ th annual ring and Zone $31-77$ th annual ring

Tablica 1. Prikaz statističkih vrijednosti rezultata određivanih makroskopskih i fizičkih svojstava u zoni 1. - 30. goda i u zoni 31. - 77. goda

\begin{tabular}{|c|c|c|c|c|c|c|c|}
\hline \multicolumn{2}{|l|}{ Zone 1-30th annual ring / Zona 1.-30. goda } \\
\hline $\begin{array}{c}\text { Property } \\
\text { Svojstvo }\end{array}$ & $\begin{array}{c}\text { Unit } \\
\text { Mjerna } \\
\text { jedinica }\end{array}$ & $\begin{array}{c}\text { Count } \\
\text { Broj } \\
\text { mjerenja }\end{array}$ & $\begin{array}{c}\text { Min value } \\
\text { Minimum }\end{array}$ & $\begin{array}{c}\text { Max value } \\
\text { Maksimum }\end{array}$ & $\begin{array}{c}\text { Average value } \\
\text { Aritmeticka } \\
\text { sredina }\end{array}$ & $\begin{array}{c}\text { Standard } \\
\text { deviation } \\
\text { Standardna } \\
\text { devijacija }\end{array}$ & $\begin{array}{c}\text { Variation } \\
\text { coefficient } \\
\text { Koeficijent } \\
\text { varijacije }\end{array}$ \\
\hline$\rho_{\mathrm{o}}$ & $\mathrm{g} / \mathrm{cm}^{3}$ & 68 & 0.512 & 0.644 & 0.596 & 0.039 & 6.575 \\
\hline$\rho_{\max }$ & $\mathrm{g} / \mathrm{cm}^{3}$ & 68 & 1.007 & 1.147 & 1.090 & 0.032 & 2.938 \\
\hline$\rho_{\mathrm{y}}$ & $\mathrm{g} / \mathrm{cm}^{3}$ & 68 & 0.453 & 0.569 & 0.522 & 0.032 & 6.039 \\
\hline$\beta_{1 \max }$ & $\%$ & 68 & 0.04 & 0.28 & 0.14 & 0.082 & 57.33 \\
\hline$\beta_{\mathrm{r} \max }$ & $\%$ & 68 & 3.50 & 5.17 & 4.50 & 0.387 & 8.607 \\
\hline$\beta_{\mathrm{tmax}}$ & $\%$ & 68 & 7.23 & 10.95 & 9.21 & 0.904 & 9.818 \\
\hline$\beta_{\mathrm{vmax}}$ & $\%$ & 68 & 11.18 & 16.54 & 14.26 & 1.207 & 8.463 \\
\hline$W_{\max }$ & $\%$ & 68 & 100.3 & 133.1 & 109.8 & 8.277 & 7.539 \\
\hline$R w$ & $\mathrm{~mm}$ & 481 & 0.31 & 10.02 & 3.41 & 1.783 & 52.24 \\
\hline Zone 31-77th annual ring $/$ Zona $31 .-77 . g o d a$ & & & & \\
\hline$\rho_{\mathrm{o}}$ & $\mathrm{g} / \mathrm{cm}^{3}$ & 101 & 0.511 & 0.643 & 0.577 & 0.036 & 6.187 \\
\hline$\rho_{\max }$ & $\mathrm{g} / \mathrm{cm}^{3}$ & 101 & 1.002 & 1.156 & 1.078 & 0.032 & 2.937 \\
\hline$\rho_{\mathrm{y}}$ & $\mathrm{g} / \mathrm{cm}^{3}$ & 101 & 0.454 & 0.560 & 0.507 & 0.027 & 5.405 \\
\hline$\beta_{1 \max }$ & $\%$ & 101 & 0.04 & 0.26 & 0.12 & 0.059 & 47.82 \\
\hline$\beta_{\mathrm{r} \max }$ & $\%$ & 101 & 3.48 & 5.03 & 4.15 & 0.391 & 9.433 \\
\hline$\beta_{\mathrm{tmax}}$ & $\%$ & 101 & 7.70 & 10.87 & 9.36 & 0.761 & 8.122 \\
\hline$\beta_{\mathrm{vmax}}$ & $\%$ & 101 & 11.48 & 15.99 & 13.87 & 1.029 & 7.415 \\
\hline$W_{\max }$ & $\%$ & 101 & 100.8 & 133.3 & 113.1 & 8.351 & 7.381 \\
\hline$R w$ & $\mathrm{~mm}$ & 732 & 0.15 & 10.31 & 3.03 & 1.671 & 55.07 \\
\hline
\end{tabular}

${ }^{a} \rho_{0}-$ density in absolutely dry condition, $\rho_{\max }-$ density at maximum moisture content, $\rho_{\mathrm{y}}-$ basic density, $\beta_{1 \max }-$ total longitudinal shrinkage, $\beta_{\mathrm{r} \max }$ - total radial shrinkage, $\beta_{\mathrm{t} \max }$ - total tangential shrinkage and $\beta_{\mathrm{v} \max }$ - total volumetric shrinkage, $W_{\max }-\operatorname{maximum}_{\operatorname{moisture}}$ content, $R w$ - annual ring width

${ }^{a} \rho_{0}-$ gustoća u apsolutno suhom stanju, $\rho_{\text {max }}$ - gustoća pri maksimalnom sadržaju vode, $\rho_{y}$ - nominalna gustoća, $\beta_{\text {max }}-$ maksimalno longitudinalno utezanje, $\beta_{r \max }-$ maksimalno radijalno utezanje, $\beta_{\text {tmax }}-$ maksimalno tangentno utezanje, $\beta_{v \max }-$ maksimalno volumno utezanje, $W_{\max }-$ maksimalni sadržaj vode, $R w$ - širina goda 
Table 2 Mann Whitney test of difference between researched macroscopic and physical properties of Zone $1-$ 30th annual ring and Zone $31-77$ th annual ring

Tablica 2. Mann Whitney test razlike između određivanih makroskopskih i fizikalnih svojstava u zoni 1. -30 . goda i u zoni 31. - 77. goda

\begin{tabular}{|c|c|c|c|c|}
\hline $\begin{array}{c}\text { Property } \\
\text { Svojstvo }\end{array}$ & $\begin{array}{c}\text { Rank } \\
\text { Sum 1 }\end{array}$ & $\begin{array}{c}\text { Rank } \\
\text { Sum 2 }\end{array}$ & $\boldsymbol{Z}$ & $\boldsymbol{p}$ \\
\hline${ }^{\mathrm{a}} \rho_{\mathrm{o}}$ & 6749.00 & 7616.00 & 3.10653 & 0.001893 \\
\hline$\rho_{\max }$ & 6617.00 & 7748.00 & 2.68334 & 0.007289 \\
\hline$\rho_{\mathrm{y}}$ & 6840.00 & 7525.00 & 3.39826 & 0.000678 \\
\hline$\beta_{1 \max }$ & 6241.00 & 8124.00 & 0.92874 & 0.353026 \\
\hline$\beta_{\mathrm{r} \max }$ & 7451.00 & 6.914 .00 & 5.35707 & 0.000000 \\
\hline$\beta_{\mathrm{t} \max }$ & 5776.50 & 8588.50 & -0.01122 & 0.991047 \\
\hline$\beta_{\mathrm{vmax}}$ & 6517,50 & 7847.50 & 2.36436 & 0.018062 \\
\hline$W_{\max }$ & 4897.00 & 9468.00 & -2.83082 & 0.004643 \\
\hline$R w$ & 315139.0 & 421152.0 & 3.88256 & 0.000103 \\
\hline
\end{tabular}

${ }^{\mathrm{a}} \rho_{0}$ - density in absolutely dry condition, $\rho_{\max }-$ density at maximum moisture content, $\rho_{\mathrm{y}}$ - basic density, $\beta_{1 \max }$ - total longitudinal shrinkage, $\beta_{\mathrm{r} \text { max }}-$ total radial shrinkage, $\beta_{\mathrm{t} \text { max }}-$ total tangential shrinkage and $\beta_{\mathrm{v} \max }$ - total volumetric shrinkage, $W_{\max }-$ maximum moisture content, $R w$ - annual ring width

${ }^{a} \rho_{0}$ - gustoća u apsolutno suhom stanju, $\rho_{\text {m }}$ - gustoća pri maksimalnom sadržaju vode, $\rho_{y}$-nominalna gustoća, $\beta_{l \max }-$ maksimalno longitudinalno utezanje, $\beta_{r \max }-$ maksimalno radijalno utezanje, $\beta_{\text {tmax }}$ maksimalno tangentno utezanje, $\beta_{v}$ - maksimalno volumno utezanje, $W_{\max }$ - maksimalni sadržaj vode, $R w$ - širina goda

sycamore maple wood in the zone from the 1st to the 30th annual ring are higher than those in the zone from the 31 st to the 77 th annual ring. Statistical comparison of density values of these two zones in sycamore maple wood shows significant differences. According to Panshin and de Zeeuw (1980), beech wood belongs to a group of species whose wood density decreases from pith to bark. Horvat (1969) and Govorčin (1996) found that density of beech wood near the pith is slightly larger than that near the bark. According to these findings and the research results shown in Table 1 and Figures 3, 4, and 5, sycamore maple wood could even be classified in the same category as beech wood, regarding wood density.

The average value of total longitudinal shrinkage of investigated sycamore maple wood in the zone from the 1 st to the 30 th annual ring is higher than in the zone from the 31 st to the 77 th annual ring, although the difference is not statistically significant. Figure 6 shows a high variability of data in radial direction, although this variability is less pronounced from about the 30th annual ring to the bark. Different authors report that longitudinal shrinkage of juvenile wood is 5 to 10 times higher (Timell, 1986; Ayrilmis, 2008). Petrić (1986) stated, based on his research on the anatomy of common beech (Fagus sylvatica L.), that juvenile wood should have a greater longitudinal shrinkage than mature wood.

The average value of total radial shrinkage in the zone from the 1st to the 30th annual ring is also higher than in the zone from the 31 st to the 77 th annual ring. The difference is statistically significant. Figure 7 shows a trend of decrease of total radial shrinkage in the zone from the pith to approximately 30th to 40th annual ring, and then a tendency of mild decrease or stagnation to the bark. According to Govorčin (1996), radial shrinkage of beech wood is $17 \%$ higher in juvenile wood than in mature wood. On the contrary, according to Timell (1986), radial and tangential shrinkage of juvenile wood should be lower than that of mature wood.

The average value of total tangential shrinkage in the zone from the 1 st to the 30th annual ring is lower than in the zone from the 31 st to the 77 th annual ring, although this difference is not statistically significant. Figure 8 does not show any difference in total tangential shrinkage from pith to bark. This is in accordance with Govorčin (1996), who also found no difference between mean values of tangential shrinkage in juvenile and mature beech wood.

The average value of total volumetric shrinkage of sycamore maple wood in the zone from the 1 st to the 30 th annual ring is higher than that in the zone from the 31 st to the 77 th annual ring. The difference is statistically significant. Such ratio agrees with Brown et al. (1949), Horvat (1976) and Panshin and de Zeeuw (1980), who state that volumetric shrinkage increases with wood density. Figure 9 shows a high variability of data in radial direction, although this variability is less

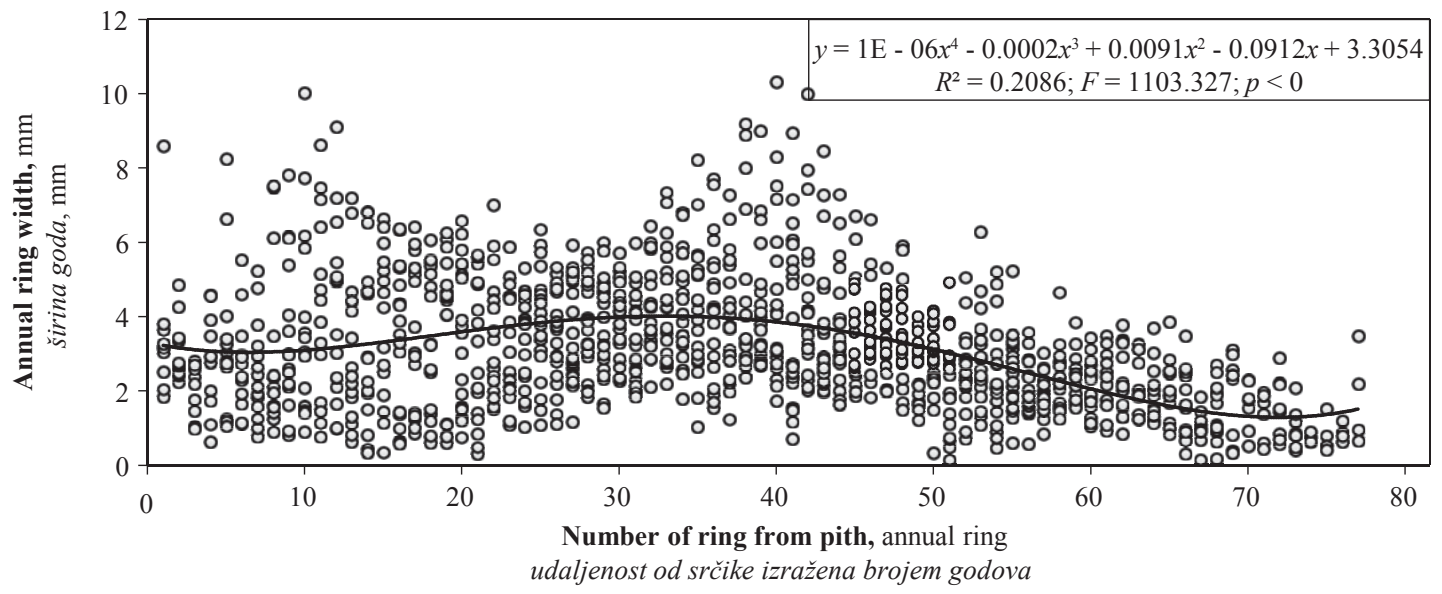

Figure 2 Radial distribution of annual ring width

Slika 2. Radijalna raspodjela širine goda 


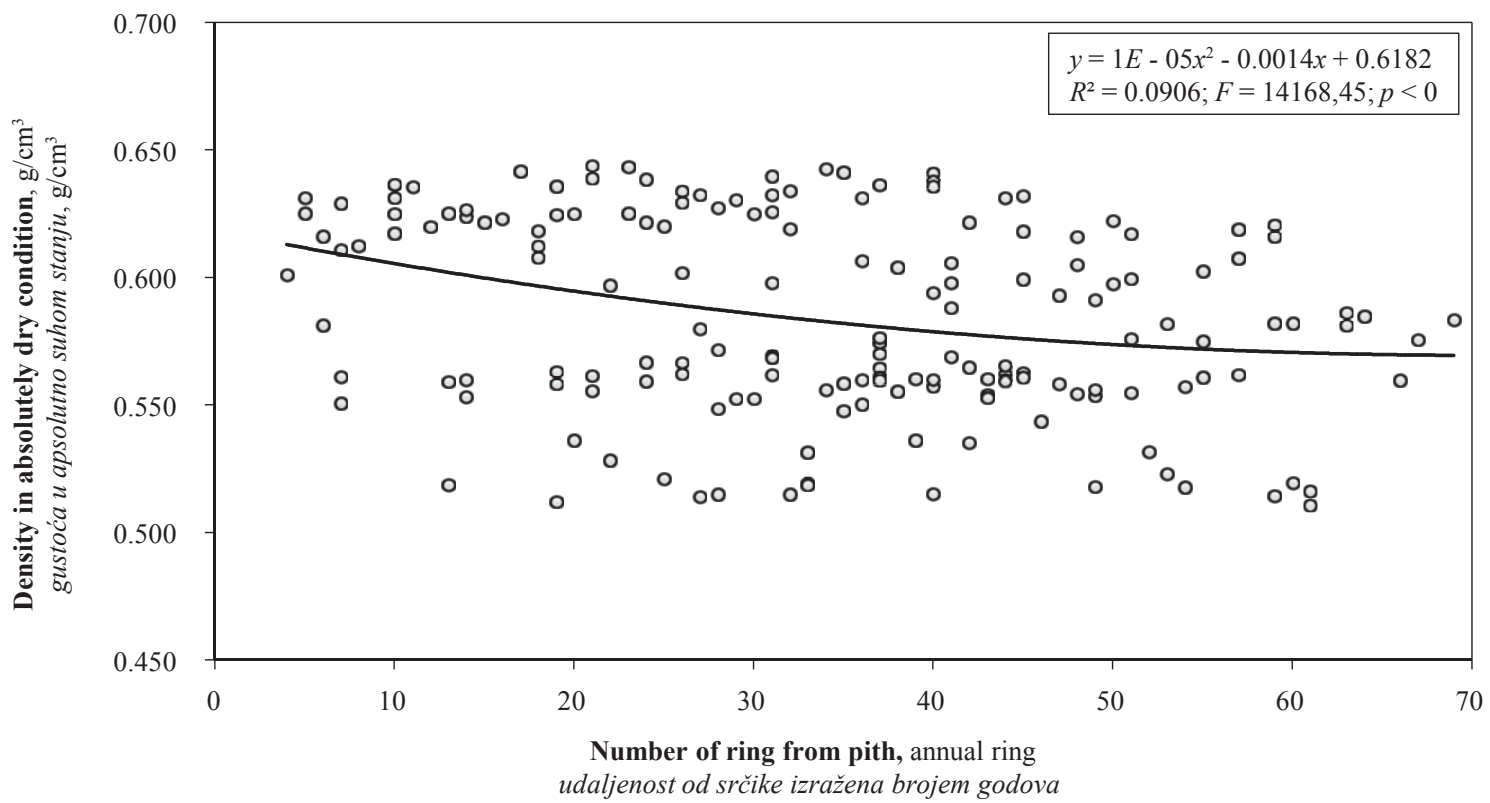

Figure 3 Radial distribution of density in absolutely dry condition

Slika 3. Radijalna raspodjela gustoće $u$ apsolutno suhom stanju

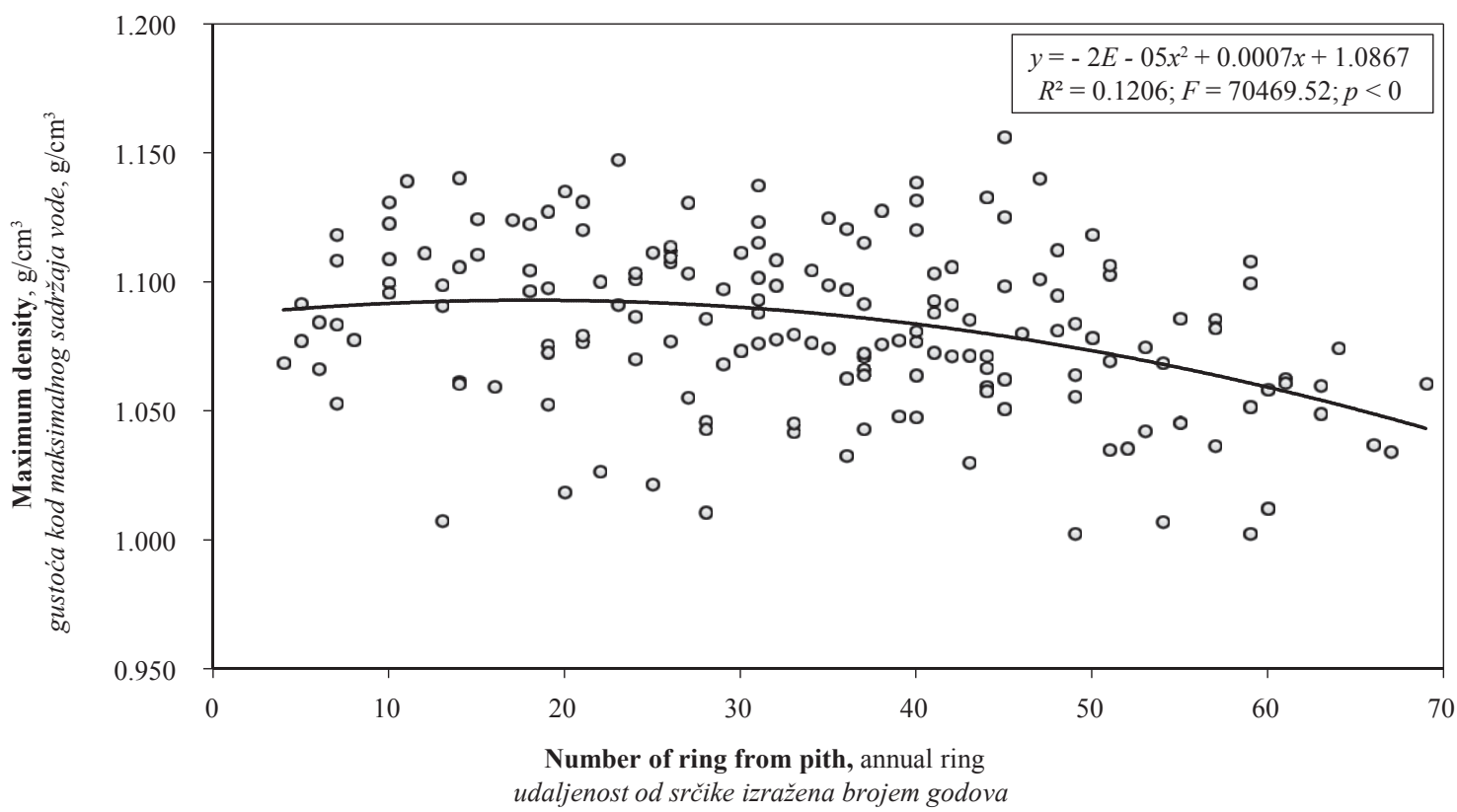

Figure 4 Radial distribution of maximum density

Slika 4. Radijalna raspodjela gustoće pri maksimalnom sadržaju vode

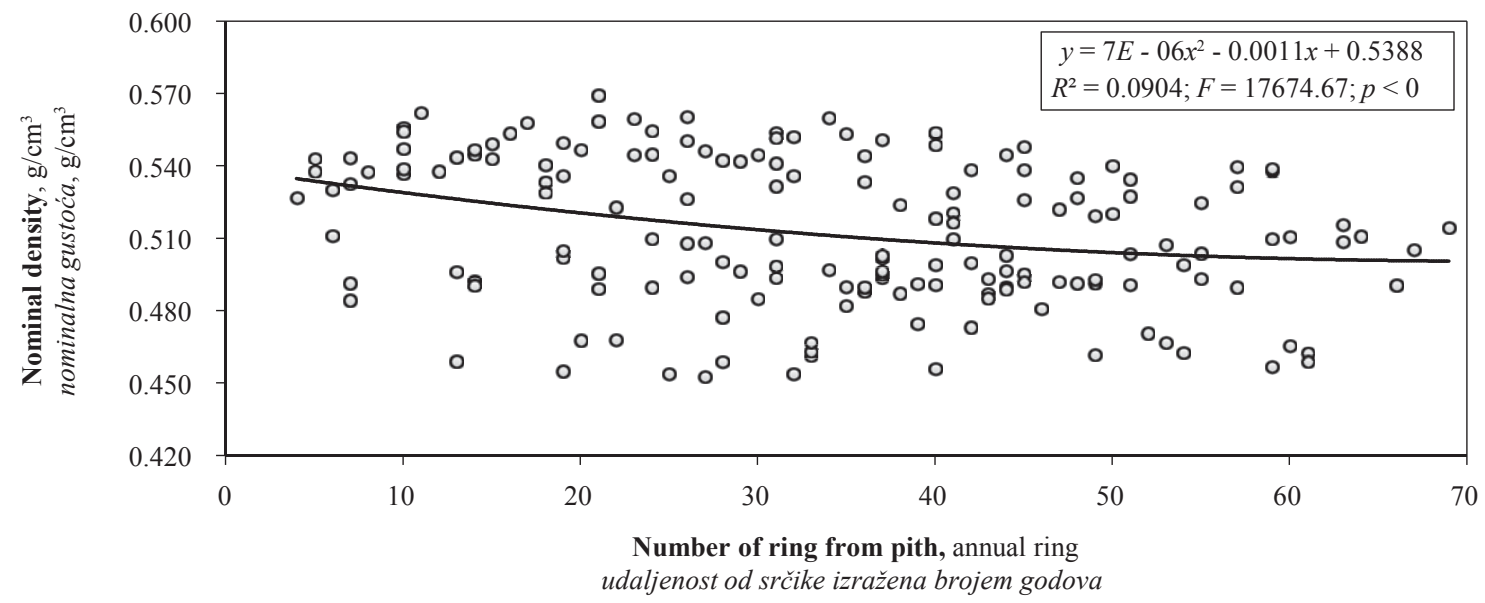

Figure 5 Radial distribution of nominal density

Slika 5. Radijalna raspodjela nominalne gustoće 


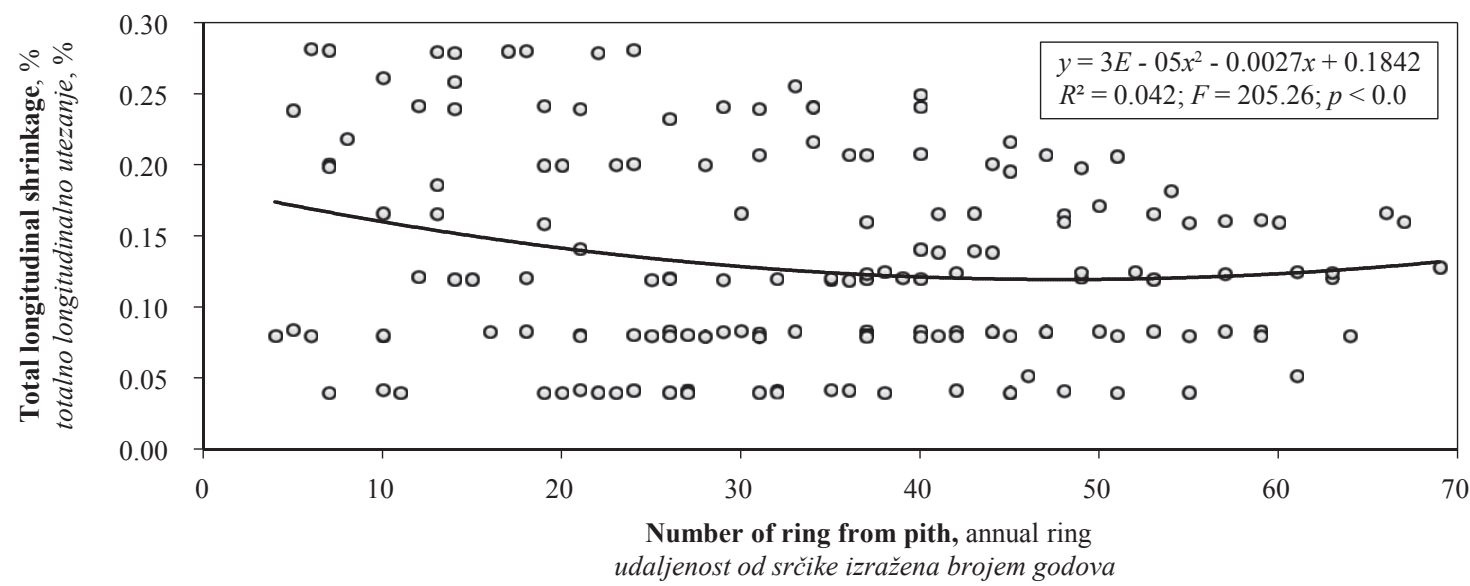

Figure 6 Radial distribution of total longitudinal shrinkage

Slika 6. Radijalna raspodjela totalnoga longitudinalnog utezanja

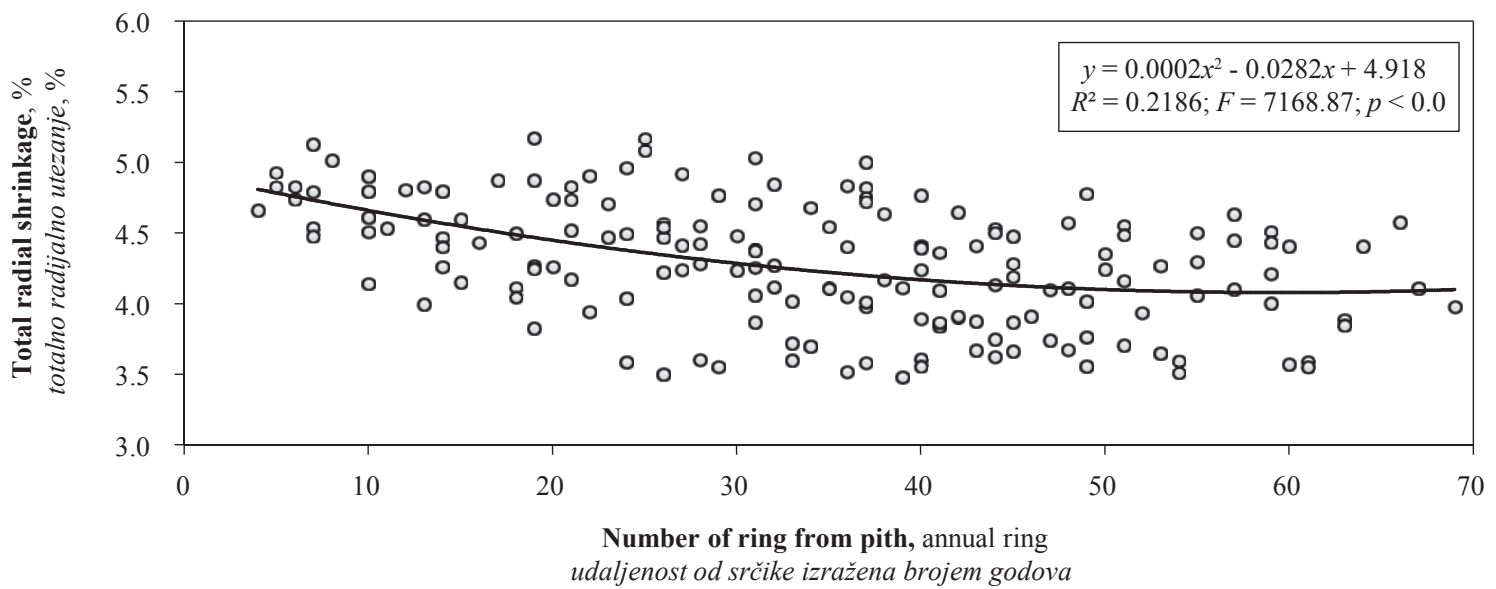

Figure 7 Radial distribution of total radial shrinkage

Slika 7. Radijalna raspodjela totalnoga radijalnog utezanja

pronounced from about 30th annual ring to the bark. According to the research of Govorčin (1996), volumetric shrinkage of juvenile wood is slightly larger than that of mature wood.

The average value of maximum moisture content in the zone from the 1 st to the 30 th annual ring is lower than in the zone from the 31 st to the 77 th annual ring. The difference is statistically significant.
This is in agreement with earlier research of Krpan (1956) and Horvat (1976). They stated that moisture content in beech wood in radial direction gradually increases from pith to bark, and that differences in moisture content of the central part and the part of the tree near the bark are not great. There is no difference in maximum moisture content from pith to bark (Figure 10).

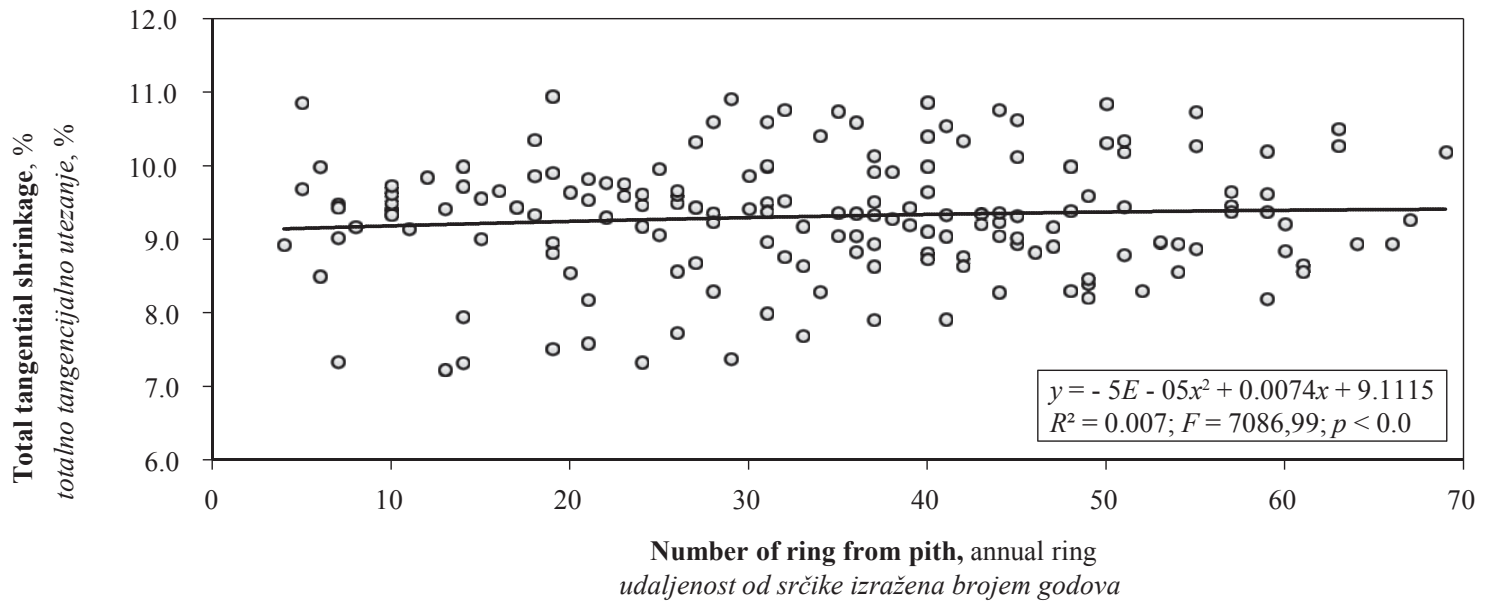

Figure 8 Radial distribution of total tangential shrinkage

Slika 8. Radijalna raspodjela totalnoga tangencijalnog utezanja 


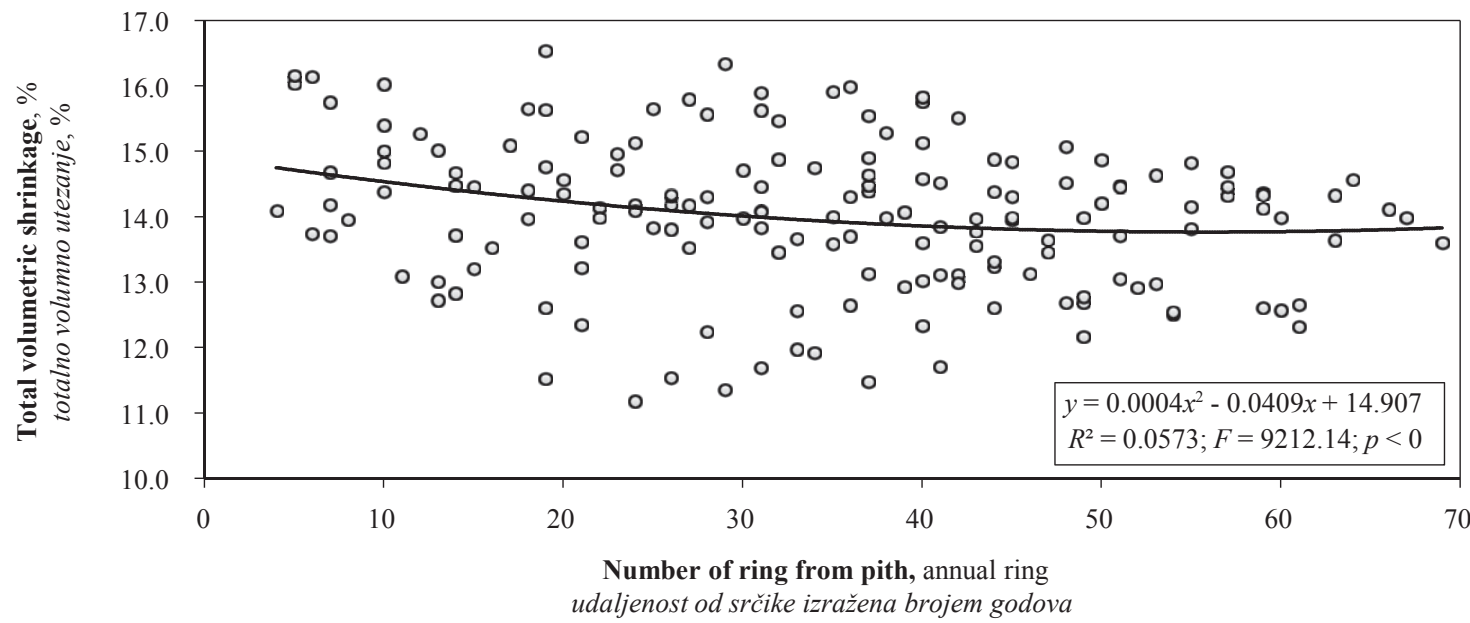

Figure 9 Radial distribution of total volumetric shrinkage

Slika 9. Radijalna raspodjela totalnoga volumnog utezanja

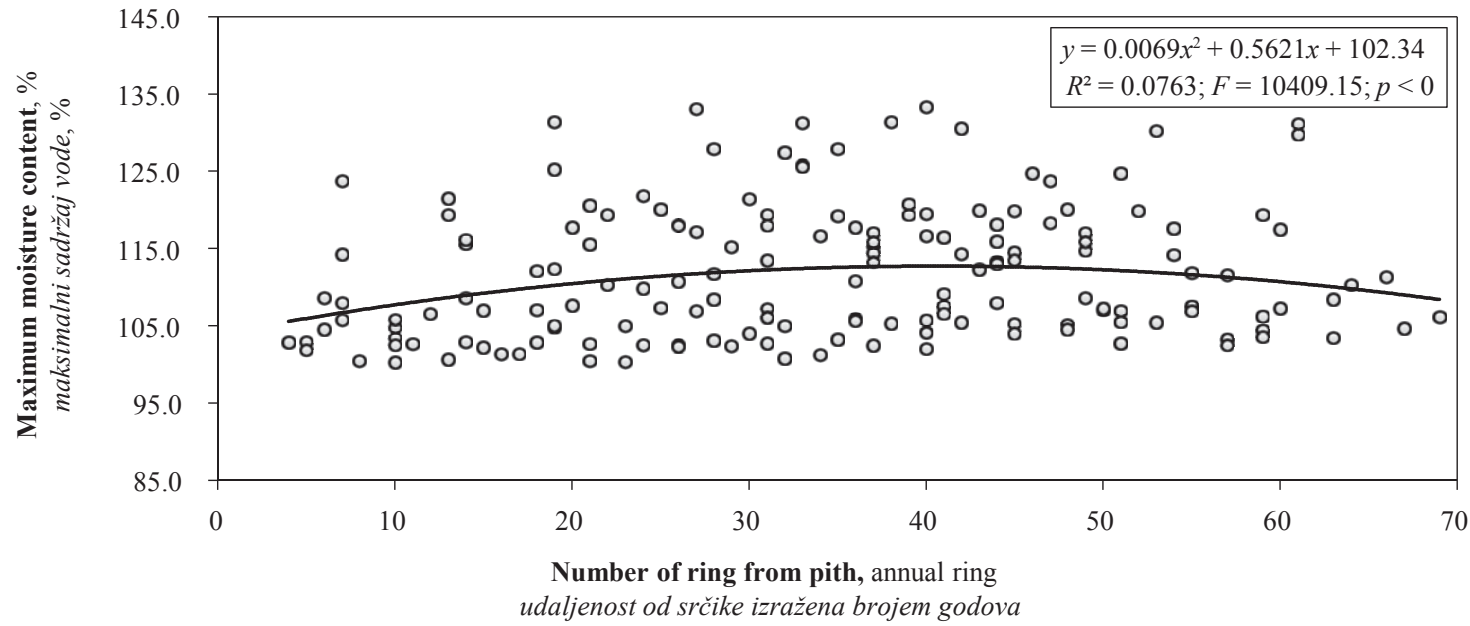

Figure 10 Radial distribution of maximum moisture content

Slika 10. Radijalna raspodjela maksimalnog sadržaja vode

\section{CONCLUSIONS}

\section{ZAKLJUČAK}

Approximately at the 30th annual ring from the pith, change in the following properties occurs: annual ring width, density in absolutely dry condition, density at maximum moisture content, nominal density, radial and volumetric shrinkage and maximum moisture content of wood.

In the cross section of sycamore maple trunk, there are two areas that differ in some studied physical properties. According to data, there is no clear distinction, although two groups show statistically significant differences. The first zone spreads from the pith to about 30th annual ring, while the other continues in the direction of the radius until the bark. Sharp boundary between the zones of juvenile and mature wood could not be determined, but transitional zone appears roughly from the 30th to the 40th annual ring from the pith.

Juvenile wood zone is recognizable by greater variability in values of studied physical properties and generally more rapid changes in property trends. Mature wood zone is characterized by less pronounced changes or even stagnation of the studied properties in comparison to juvenile wood.
Wood processing prefers high annual growth rate and uniformity in technical properties of material. For better prediction of wood quality of sycamore maple, investigation of anatomical and mechanical properties should be carried out.

\section{REFERENCES}

\section{LITERATURA}

1. Ayrilmis, N., 2008: Effect of compression wood on dimensional stability of medium density fiberboard. Silva Fennica 42(2): 285-293. https://doi.org/10.14214/sf.257.

2. Brown, H. P.; Panshin, A. J.; Forsyth, C. C., 1949: Texbook of wood technology, Vol. 1. N.Y.

3. Govorčin, S., 1996: Svojstva juvenilnog i adultnog drva bukovine iz područja Bjelolasice. Doktorska disertacija. Šumarski fakultet Sveučilišta u Zagrebu.

4. Horvat, I., 1969: Osnove fizičke i mehaničke karakteristike bukovine. Drvna industrija, 20 (11-12): 183-194.

5. Horvat, I., 1976: Tehnologija drva, 1. dio. Zagreb, 1976.

6. Kleinschmit, J.; R. G. Kleinschmit, J., 2009: Genetics and Tree Breeding. In Spiecker, Hein, \& Makkonen\&Spiecker, Valuable Broadleaved Forests in Europe (pp. 45-60). Boston: European Forest Institute: Research report 22.

7. Kölling, C., 2007: Klimahüllen für 27 Waldbaumarten. Allgemeine Forstzeitschrift/Der Wald. 23: 1242-1245. 
8. Kölling, C.; Zimmermann, L., 2007: Die Anfälligkeit der Wälder Deutschlands gegenüber dem Klimawandel. Gefahrstoffe, 67: 259-268.

9. Krabel, D.; Wolf, H., 2013: Sycamore maple (Acer pseudoplatanus L.). In: Pa^ques L.E. (ed.). Forest tree breeding in Europe. Springer, Netherlands, 373-402.

10. Krpan, J., 1956: Sadržaj vode u sirovoj bukovini. Šumarski list, 80 (11-12): 386-392.

11. Panshin, A. J.; de Zeeuw, C., 1980: Textbook of wood technology, McGraw-Hill Book Company, New York.

12. Petrić, B.; Bađun, S., 1985: Strukturne karakteristike i svojstva juvenilnog drva. Bilten ZIDI, 13 (6): 91-112.

13. Petrić, B., 1986: Značaj svojstava drva kao sirovine u tehnologiji drva s osvrtom na bukovinu. Kolokvij o bukvi, Velika - Zagreb, 17-23.

14. Rusanen, M.; Myking, T., 2003: EUFORGEN Technical Guidelines for genetic conservation and use for sycamore (Acer pseudoplatanus). International Plant Genetic Resources Institute, Rome, Italy, 6 pp.

15. Senft, J. F., 1986: Practical significance of juvenile wood for the user. 18th IUFRO Congress, Ljubljana, Division 5, For. Pro., 7: 261-270.

16. Spethmann, W.; Namvar, K., 1985: Der Bergahorn und die Gattung Acer. Allgemeine Forstzeitschrift, 42: 11261131.

17. Thies, M.; Hein, S.; Spiecker, H., 2009: Results of a Questionnaire on Management of Valuable Broadleaved Forests in Europe. In Spiecker, Hein, Makkonen Spiecker, \& Thies, Valuable Broadleaved Forests in Europe (pp. 27-42). Boston: European Forest Institute: Research Report 22.

18. Timell, T. E., 1986: Compression wood in gymnosperms. Vol. 3. Springer-Verlag, 2150 p., Berlin - Heidelberg, Germany.
19. Vukelić, J., 1998: Sveučilišna šumarska nastava u Hrvatskoj 1898 - 1998. Knjiga IV. Nastavno-pokusni šumski objekti Šumarskog fakulteta Sveučilišta u Zagrebu, Zagreb.

20. Zobel, B. J.; Van Buijtenen, J. P., 1989: Wood variation - its causes and control. Springer, Berlin, Germany.

21. *** HRN D.A1.042-1957: Ispitivanje drva Karakteristične osobine - Mjerenje.

22. *** HRN ISO 3129:1999: Drvo - Postupci i odrednice pri uzimanju uzoraka za ispitivanje fizikalnih i mehaničkih svojstava.

23. *** HRN ISO 3130:1999: Drvo - Određivanje sadržaja vode za ispitivanje fizikalnih i mehaničkih svojstava.

24. ${ }^{* * *}$ HRN ISO 3131:1999: Drvo - Određivanje gustoće za ispitivanje fizikalnih i mehaničkih svojstava.

25. *** HRN ISO 4469:1999: Drvo - Određivanje radijalnog i tangencijalnog utezanja.

26. *** HRN ISO 4858:1999: Drvo - Određivanje volumnog utezanja.

27. *** Hrvatske šume, 2014. Usporedba plana sječe sa izvršenjem sječe od 01.01.2006 do 31.12.2013.

\section{Corresponding address:}

IVA IŠTOK, Ph.D.

University of Zagreb

Faculty of Forestry

Svetošimunska 25

HR-10002 Zagreb, CROATIA

e-mail: iistok@sumfak.hr 